\title{
The Effect of Capital Structure on Profitability of Basic Materials Saudi Arabia Firms
}

\author{
Alwalid Mohammad Saleh A. Hajisaaid \\ Science in Finance, Riyadh, KSA \\ Email: Alwalid.hajisaaed@gmail.com
}

How to cite this paper: Hajisaaid, A.M.S.A. (2020) The Effect of Capital Structure on Profitability of Basic Materials Saudi Arabia Firms. Journal of Mathematical Finance, 10, 631-647.

https://doi.org/10.4236/jmf.2020.104037

Received: July 31, 2020

Accepted: November 3, 2020

Published: November 6, 2020

Copyright $\odot 2020$ by author(s) and Scientific Research Publishing Inc. This work is licensed under the Creative Commons Attribution International License (CC BY 4.0).

http://creativecommons.org/licenses/by/4.0/

(c) (i) Open Access

\begin{abstract}
This research investigated the relationship between capital structure and profitability of eight companies working in the basic material sector in Saudi Arabia during the period 2009 to 2018. The statistical techniques used are regression analysis, fixed effect model, random effect model, and Hausman test. The dependent variable is the return on equity $(R O E)$. In contrast, independent variables are a short-term debt to total assets ratio $(S D A)$, long-term debt to total assets ratio $(L D A)$, and total debt to total assets ratio $(D A)$. The results illustrate a negative relationship between short-term debt to total assets ratio $(S D A)$ and profitability and this complement with studies like Hamid and others (2015) [1] and Abeywardhana (2015) [2], a negative relationship between long-term debt $(L D A)$ and profitability which complement with studies like El-Sayed Ebaid (2009) [3], and positive relationship between total debt $(D A)$ and profitability which complement with studies like Abor (2005) [4], Hamid and others (2015).
\end{abstract}

\section{Keywords}

Capital Structure, Return on Equity, Short-Term Debt, Long-Term Debt, Total Debt

\section{Introduction}

The capital structure is the mix of the external fund and internal fund that a firms use in its major operation and varieties of securities. For example, lease financing to acquisition on new assets, and issue bonds. Firms can also issue new common stocks or preferred stocks to maximize shares in the market and enter new projects (Abor, 2005). The capital structure will raise the agency cost between the shareholders and managers, and thus between debt holders and equity holders (Jensen and Meckling, 1976) [5]. Many studies illustrate that growth 
opportunity plays a significant role in determining the capital structure and therefore impact profitability. If the firm relies solely on self-financing to take advantage of expansion opportunities, it may face difficulty obtaining the targeted financing, and therefore external financing helps in achieving this goal; thus, it will reflect positively on firm profitability (Hovakimian, Opler, and Titman, 2001) [6]. Consequently, the higher debt ratio to firm leads a higher risks and interest ratio. If the firms do not acquire sufficient operating cash flow plus tax payment and interest payment, it will examine a risks insolvency and go to bankruptcy (Azhagaiah and Gavoury, 2011) [7].

The component of financial leverage used in this study is short-term debt to total assets, long-term debt to total assets, and total debt to total assets. Studies illustrate a positive relationship between leverage level and firm profitability (Taub, 1975; Roden and Lewellen, 1995; Ghosh et al., 2000; Hadlock and James, 2002) [8] [9] [10] [11]. The interest of using leverage relays on leverage ratio of the firm's investment decision. The enterprise value is identified by funding new investment (Salawu, 2007) [12]. The basic materials sector is a category of stocks for companies involved in the discovery, development, and processing of raw materials. The sector includes companies engaged in mining and metal refining, chemical products, and forestry products. The companies supply most of the materials used in construction. Thus, they are sensitive to changes in the business cycle and tend to thrive when the economy is strong. Companies included in the basic materials sector are involved in the physical acquisition, development, and initial processing of the many products commonly referred to as raw materials. Raw materials are naturally occurring substances and resources dividing into finite and reusable. The most common materials within the sector include mined products, such as metals like gold and ore like oil, and forestry products, such as lumber and paper. The stocks of certain chemical producers and energy sources also are included in the basic materials sector. Containers and packaging also are considered basic materials, whether they are producing glass, metal, or cardboard. The basic materials sector in the Saudi stock market is the largest in the market, with a value of SR 509 billion $^{1} .42$ public companies worked in producing cement, oil, glasses, plastic, chemicals and metals and several sectors have been merged with petrochemicals to become the largest. The objective of the study is to investigate the relationship between capital structure and profitability of the firm in the basic materials sectors in Saudi Arabia during the period 2009 to 2018 .

The scope of the study is eight firms of the basic material sector: Saudi Basic Industries Co. (SABIC), Zamil Industrial Investment Co. (ZIIC), Saudi Kayan Petrochemical Co. (KAYAN), Saudi Arabian Mining Co. (MAADEN), Yanbu National Petrochemical Co. (YANSAB), Sahara International Petrochemical Co. (SIPCHEM), Saudi Steel Pipe Co. (SSP) and Saudi Industrial Investment Co. (SIIG). The main goal of any company is to maximize shareholder wealth by inhttps://www.aleqt.com/article/1117836/\%D8\%A7\%D9\%84\%D8\%B3\%D8\%B9\%D9\%88\%D8\%AF\% D9\%8A\%D8\%A9. 
creasing net profit. Furthermore every kind of fund either external or internal has a cost, so the manager should determine the optimal option of fund, especially in the environment that fever of competences is high. Thus, the results of this study are helping the managers in the firms to make the right decisions to use the optimal amount of internal and external funds to increase profitability.

\section{Research questions}

This research aims to answer the following questions:

1) What are the relationships between short-term debt to total assets ratio and return on equity?

2) What are the relationships between long-term debt to total assets ratio and return on equity?

3) What are the relationships between total debt to total assets ratio and return on equity?

\section{Literature Review}

In this study, 20 scientific papers were published on the relationship between the capital structure and the profitability of companies in several different countries in which the authors used several dependent and independent variables in addition to different statistical techniques to obtain whether there is a positive or negative relationship or there is no relationship between the capital structure And profitability. The results of each scientific paper were also linked to each other, in addition to the gaps in each study and their effect on the extracted results were presented.

Mesquita and Lara (2003) [13] investigate the correlation among the capital structure and profitability of 70 number of a Brazilian company in industrial, commercial, and services sectors during the period 1995-2001. The study's dependent variable is the return on equity $(R O E)$, while the independent variable was the short-term debt to total liability (ECP), long-term debt to total liability (ELP), and a total of owner's equity to total equity (PL). The statistical technique used is Ordinary Least Squares (OLS). The results illustrate the positive relationship between return on equity with short-term debt and a total of the owner's equity in correspondingly negative correlation with long-term debt. The authors relied on one statistical technique in analyzing the data in addition to the fact that the study was in a second world country, which would weaken the data.

Abor (2005) criticizes the impact of capital structure on profitability on listed firms of the Ghana Exchange (GSE) for five years. The dependent variable used in this study is Return on equity ( $R O E$ ), while independent variables are Short-term debt to total assets $(S D A)$, Long-term debt to total assets $(L D A)$, and Total debt to total assets $(D A)$. The statistical technique used is regression analysis. The results illustrate that significant positive relationship between the ratio of short-term debt to total assets $(S D A)$ and profitability, a negative relationship between the ratio of long-term debt to total assets $(L D A)$ and profitability and a significantly positive association between the ratio of total debt $(D A)$ to total assets and profitability. The results indicate that the increase in short-term debt and total debt 
is causing to raise profitability, but on the otherwise increasing in long-term debt will reduce profitability. The author relied on a single statistical technique in his analysis of the data, which would weaken the data, in addition to the fact that the study was in an emerging country, in which the extracted data is biased or inaccurate, which would make the data useless.

Salawu and Awolowo (2007) examine the effect of capital structure on profitability from the listed company in Nigeria secondary data from 1990 to 2004. The dependent variable is earnings before interest and tax to the book value of total assets, correspondingly the independent variables is Total liabilities ratio, Long-term liabilities ratio, and Short-term liabilities ratio. The statistical techniques used for analysis are The Pooled Ordinary Least Squares (OLS) model, Fixed Effect Model (FEM), and Random Effect Model (REM), and the estimation model used is panel data. The results illustrate a positive correlation between profitability and short-term debt and equity but the inverse correlation with long-term debt; the results also demonstrate a negative association between the ratio of total debt to total assets (LEV1) and profitability. The study was conducted in an emerging country, and the data used may be inaccurate, in addition to that the author relied on the book value of the assets and not the market value. Therefore, this data cannot be applied on the ground or used for forecasting.

Ebaid (2009) explores the impact of capital structure on firm performance in Egypt. The data used is a non-financial Egyptian listed firm from 1997 to 2005. The dependent variables are Return on equity $(R O E)$, Return on assets (ROA), and Gross profit margin (GM). On the other hand, the independent variable was incorporate Short-term debt to assets (STD), Long-term debt to assets (LTD), and Total debt to assets (TTD). The statistical technique used is multiple regression analysis. The dependents variables have a significant negative relationship with independent variables. The author used one technique for additional analysis, which would weaken the data in addition to the fact that the study was in an emerging country and not a member of any international organization that obliges it to publish reports and data periodically, so the data used may be biased. The country is also located in a hot geographical and political area which what happens around its borders may affect its economy

Azhagaiah and Gavoury (2011) try to prove there is a relationship between capital structure and profitability on a list of 201 information technology firms in the Bombay Stock Exchange in India through the period 1999 to 2007. The dependent variables are the return on assets (ROA) and return on capital employed (ROCE), while independent variables are a total debt to total assets ratio (TD_TA), the expense to income ratio (EXP_INC), debt-equity ratio (DER) and current ratio (CR). The statistical technique used is Regression analysis. The results show a negative relationship between total debt to total assets ratio, the expense to income ratio, debt to equity ratio, and current ratio with profitability. The author used one statistical technique which may lead to inaccurate data.

Gill et al. (2011) [14] study the impact of capital structure on the profitability 
of a sample of 272 American service and manufacturing firms listed on the New York Stock Exchange (NYSE) during the period from 2005 to 2007. The statistical techniques are correlation and regression analysis. The dependent variable is the return on equity $(R O E)$ on the otherwise independent variables are a short-term debt to total assets $(S D A)$, long term debt to total assets $(L D A)$, and total debt to total assets $(D A)$. The results are a positive relationship between short-term debt to total assets ratio and total debt to total assets ratio with profitability in the service industry while positive relationship between all independent variables and profitability in the manufacturing industry. The period used in the study is only two years, which is very short, which may produce inaccurate and useful data for use.

San and Heng (2011) [15] criticize the impact of the capital structure of profitability in the structure firms listed in the Main Board of Bursa Malaysia classification as big, medium, and small during the period 2005 to 2008. The dependent variables are the return on capital (ROC), return on equity $(R O E)$, return on assets (ROA), earnings per share (EPS), operating margin (OM), net margin (NM). Independent variables are a long-term debt to capital (LDC), debt to capital (DC), debt to assets $(D A)$, debt to equity market value (DEMV), debt to common equity (DCE), and long-term debt to common equity (LDCE). The statistical technique using is ordinary least square (OLS). The results showing return on capital (ROC) with debt to equity market value (DEMV) and earning per share (EPS) with long-term debt to capital (LDC) have positive relationships whereas earning per share (EPS) with debt to capital have a negative relationship. Correspondingly, in the medium companies, operating margin (OM) with long-term debt to common equity (LDCE) has a positive relationship and against in the small companies earning per share (EPS) with debt to capital (DC) has a negative relationship. The study period is too short which may lead to inaccurate and useful results.

Soumadi and Hayajneh (2012) [16] investigate the impact of capital structure on the profitability of the 76 listed in the Amman stock market for the period 2001 to 2006. The dependent variables, which are return on equity (ROE) and firm value, which is market value of owner equity plus book value of total liabilities to the book value of total assets. There are four independent variables financial leverage, tangible assets, firm size, and firm growth. The statistical techniques used are the multiple regression models represented by ordinary least squares (OLS). The results illustrate negatively relationship on firm value. There is a positive relationship between size and growth firm on firm performance, and Tangible assets are correlated negatively with performance. The study was conducted in an emerging country, and the data obtained are inaccurate. Also, the author used only one statistical technique which may weaken the extracted data.

Salim and Yadav (2012) [17] study the relationship between capital structure and firm performance on sample 237 Malaysian listed companies on the Bursa Malaysia Stock exchange during the period 1995-2011. The dependent variables are the return on equity $(R O E)$, return on assets $(\mathrm{ROA})$, and earning per share 
(EPS). On the other hand, the independent variables were short-term debt to total assets (STD), long-term debt to long term debt plus equity (LTD), and total assets minus total equity to total assets (TD). The statistical technique used is regression analysis. The results extracts are negative relationship between independent variables and dependent variables. The authors relied only on one technique that may produce results that are not valid or beneficial for use.

Velnampy and Niresh (2012) [18] have studied the relationship between capital structure and profitability on the ten listed Sri Lankan banks over the eight years from 2002 to 2009. The study dependent variables are Net profit ratio, Return on capital employed (ROCE), Return on equity $(R O E)$, and net interest margin (NIM). In contrast, the independent variables are Debt to equity and Debt to total funds ratio. The results show negative relationship between all dependent and independent variables, except the links among debt to equity and return on equity showed a positive. The author relied only on data from one sector in research and analysis, which the extracted results may not be useful for generalizing to other sectors due to the difference in characteristics. Also, the author used data from an emerging country and it is not a member of any international organization that obliges it to publish periodic and accurate information, so the data used may be inaccurate.

Addae et al. (2013) [19] clarified the relationship between capital structure and profitability on listed companies in Chana during the period 2005 to 2009. The dependent variable is the return on equity ( $R O E)$ against the independent variables are a short-term debt to total capital $(S D A)$, long-term debt to total capital $(L D A)$, and total debt to total capital $(D A)$. The statistical technique used is regression analysis. The results show a positive relationship between profitability and short-term debt, a negative relationship between profitability and long-term debt, and a negative relationship between total debt and profitability. The study period is short, which would make the data used not useful. In addition, the study was set up in an emerging country in addition to that the author used only one dependent variable.

Ahmad (2014) [20] studied the effect of capital structure on profitability in 16 cement firms listed in Karachi Stock Exchange during the period 2005-2010. The dependent variable is the return on equity $(R O E)$, while independent variables are a debt to equity ratio (DER), debt ratio (Dr), interest coverage ratio (ICR), short-term debt to assets (STDA) and long-term debt to assets (LTDA). The statistical technique used is STATA 11. The results implied a negative relationship between debt to equity ratio, debt ratio, interest coverage ratio, long-term debt to equity with return on equity, while a positive relationship between short-term debt and return on equity. The author used only one dependent variable, he also used one statistical technique, in addition to the fact that the study was in an emerging market which would make the data inaccurate.

Tailab (2014) [21] studied the relationship between capital structure and performance of a sample 30 Energy American firms from 2005 to 2013. The dependent variables are the return on assets (ROA) and return on equity $(R O E)$, while 
independent variables are a short-term debt to total assets (STD), long-term debt to total assets (LTD), and total debt to total assets (TD). The statistical technique used is Partial Least Square (PLS). The results clarify negative relationship between short-term debt to total assets ratio with profitability while the negative relationship between total debt to total assets ratio and profitability and finally insignificant either negative or positive relationship between long-term debt to total assets ratio and profitability. The author relied in his study on one sector only and did not take more than one sector and used one statistical technique which would make the data inaccurate.

Yegon et al. (2014) [22] studied the relationship between capital structure and profitability in the banking sector in Kenya empirically during the period 2004 to 2012. The dependent variable is the return on equity ratio (ROE), while the independent variables were short-term debt to total assets (SAD), long-term debt to total assets $(L D A)$, and total debt to total assets $(D A)$. The statistical techniques used are Ordinary Least Squares (OLS) and regression analysis. The results illustrate a positive relationship between short-term debt and profitability; meanwhile, they show a negative relationship between long-term debt and profitability and no effects by total debt to profitability. The author relied on one dependent variable, also the study was in an emerging country in addition to the statistical techniques used are only one, which weakens the results.

Hamid et al. (2015) investigate the impact of capital structure on the profitability of 46 family and non-family firms in Malaysia during the period 2009 to 2011. The dependent variable is the return on equity $(R O E)$, while independent variables in this examine are a short-term debt to total assets ratio $(S D A)$, long-term debt to total assets ratio $(L D A)$, and total debt to total assets (TDA). The statistical techniques using in this study are the Mann-Whitney U Test, Correlation matrix, and Multivariate analysis. The results illustrate a negative relationship between short-term debt ratio, long-term debt ratio, and total debt ratio with profitability. The study was in an emerging country, in addition to that, the study period was short and the dependent variable used is only one, which weakens the extracted data.

Abeywardhana (2015) studied the impact of capital structure on the profitability of non-financial SMEs firms in the UK during the period from 1998 to 2008. The dependent variables are the return on assets ratio (ROA) and return on the capital-employed ratio (ROCE) while independent variables are a debt to equity (GERINGR), total debt to total assets (TD), long-term debt to total assets (LTD), short-term debt to total assets (STD) and short-term debt to total debt (STDTD). The statistical technique used is Two-Stage Least Squares (2SLS). The results are illustrate a negative relationship between capital structure ratios and performance ratios. The study was on small and medium-sized companies, which the extracted results may not be useful to track for large and giant companies, in addition to that the author relied only on one holding technique, which would weaken the extracted data.

Movalia (2015) [23] investigated the relationship between capital structure 
and profitability on 14 tires companies listed in BSE and NSY in India. The dependent variables are net profit ratio, return on net worth, and return on capital employed while the independent variable is debt to equity ratio. The statistical technique used is Durbin Watson Statistics. The results illustrate a positive relationship between debt to equity ratio and performance ratios. The study was in an emerging country, also the author used one statistical technique in addition to that the independent variable was only one, and moreover only the study was restricted to a few companies, which all this would weaken the extracted data.

Semuel and Widjojo (2016) [24] discuss the relationship between capital structure and profitability on 29 property and construction companies in Indonesia through the period 2009-2013. The dependent variables are the return on assets (ROA), return on equity (ROE), gross profit margin (GM) and net profit margin (NM) while independent variables are a total debt to total assets (TDTA), total debts to total equities (TDTE), long-term debts to total assets (LTDTA) and short-term debts to total assets (STDTA). The statistical techniques used are Outer Loadings and Path Coefficients. The results illustrate a positive relationship between all debt ratios and profitability ratios. The study was conducted in an emerging country and the data used may be inaccurate or clear.

Anrfo and Appiahene (2017) [25] investigate of the relationship between capital structure and profitability on banks in 37 countries in Africa during the period 2009-2015. The dependent variables are risk-adjusted return on asset (RAROA), risk-adjusted return on equity (RAROE), and net interest margin (NIM) while the independent variable is debt ratio (DR). The statistical technique used is dynamic panel regression robust analysis. The results illustrate positive relationships between debt ratio and all dependent variables. The authors used only one statistical technique for the analysis, in addition to the fact that the study was only on the banking sector, which may not generalize and apply the extracted results to other sectors.

Singh and Singh (2016) [26] study the effect of capital structure on performance on top ten cement companies that represent $90 \%$ of the total market share of the cement industry in India during the period 2009-2013. The dependent variables are gross profit, return on capital, and return on equity, while independent variables are debt to equity and debt to total funds. The statistical technique used is the Pearson correlation. The results illustrate a negative relationship between all independent variables ratios and all dependent variables ratios. In their study, the two authors used data for only one sector that is the cement sector, in addition to that they used one statistical technique, which would make the data unedited or accurate.

For the summery of the results and form the long-term perspective, the study by San and Heng (2011) shows a positive relationship with profitability, and this study complements the study by Gill et al. (2011). Other studies illustrate negative relationship like Ebaid (2009) and Salawu and Awolowo (2007) and Abor (2005) and Addea et al. (2013) and Mesquita and Lara (2003) Salim and Yadav 
(2012) Yegon et al. (2014) and Hamid and others (2015) and Abeywardhana (2015) and Ahmad (2014).

From the short-term debt perspective the study by Salawu and Awolowo (2007) showing a positive relationship with profitability and this study complement with the study by Abor (2005) and Addea et al. (2013) Mesquita and Lara (2003) and Ebaid (2009) and Salim and Yadav (2012) and Yegon et al. (2014) Gill et al. (2011) and Tailab (2014) and Ahmad (2014). Other studies illustrate negative relationships like Hamid et al. (2015) and Abeywardhana (2015).

From the total debt perspective, the study by Abor (2005) shows a positive relationship with profitability and this study complement with the study by Hamid et al. (2015) and San and Heng (2011) and Gill et al. (2011) and Movalia (2015). Other studies illustrate negative relationship like Ebaid (2009) and Salawu and Awolowo (2007) and Soumadi and Hayajneh (2012) and Addea et al. (2013) and Salim and Yadav (2012) and Tailab (2014) and Azhagaiah and Gavoury (2011) and Abeywardhana (2015) and Ahmad (2014). Other studies illustrate no effecting like Yegon et al. (2014) and Anrfo and Appiahene (2017) and Singh and Singh (2016).

\section{Methodology and Data}

\section{Type of Study}

The study covers the period from 2009 to 2018 using cross-sectional data by Bloomberg terminal, https://www.bloomberg.com/europe.

The Model

The following regression models are estimated: (Abor 2005), (Gill, et al., 2011).

$$
\text { ROEit }=\beta 0+\beta 1 D A i t+\beta 2 L D A i t+\beta 3 D A i t+\beta 4 \text { Sizeit }+\beta 5 S G i t+e 3
$$

where:

$\beta 0$ : The intercept of the equation.

$\beta$ : Coefficients for independent variables.

$R O E$ : Net Income/average equity.

$S D A$ : Short-term debt/total assets.

$L D A$ : Long-term debt/total assets.

$D A$ : Total debt/total assets.

Size: Natural Logarithm of the firm's sales, lagged one-year period.

$S G$ : Current year's sales minus the previous year's sales divided by the previous year's sales.

i: firm.

$t$. time $=1,2, \ldots, 10$ years.

eit $=$ Error term

\section{Statistical Analysis Techniques}

1) Regression Analysis: used to investigate the relationship between capital structure and profitability measured by $R O E$.

2) Fixed Effect Model: regression model in which the group means are fixed 
(non-random).

3) Random Effect Model: used in panel analysis of hierarchical or panel data when one assumes no fixed effects (it allows for individual effects).

4) Hausman Test: (Hausman 1978) are tests for econometric model misspecification based on a comparison of two different estimators of the model parameters.

5) Pearson Correlation: used to identify the direction to statistical relationships between independent variables and the dependent variables.

\section{Hypotheses and Conceptual Framework}

H01: There is a positive relationship of short-term debt on total assets and profitability.

H02: There is a positive relationship of long-term debt on total assets and profitability.

H03: There is a positive relationship of total debt on total assets and profitability.

\section{Data Collection Method}

The cross-sectional data. Extract data from Bloomberg website from 2009-2018.

Population and Study Sample

All basic materials shareholding companies that satisfy the following conditions will incorporate in the study sample:

1) Share price data are available during the study period (2009-2018), and there is an availability of data required to calculate study variables.

2) The company did not enter in a consolidation process or allocated free shares because these events affect the company figures such as earnings.

\section{Results and Interpretation of Results}

\section{Descriptive Statistics}

Table 1 provides a summary of the descriptive statistics of the dependent and independent variables for the sample of firms. The profitability measured by return on equity $(R O E)$ reveals an average of 8.36 percent, with a median of 8.74 percent. On the other hand, it suggests a bad picture for Jordanian companies when comparing with El-Sayed Ebaid (2009) study on Egyptian companies; ROE average was 21.37 percent, with a median 21.17 percent, and with Abor (2005) study on Ghana companies; $R O E$ average was 36.94 percent.

The variable $S D A$ measures the ratio of short debt to total assets, and the average value of this variable is 8.45 percent, with a median of 4.2 percent. This value indicates that short-term debts represent approximately 8.45 percent of total assets. The variable $L D A$ measures the ratio of long-term debt to total assets. The average value of this variable is 32.07 percent, with a median of 36.17 percent, in which this value indicates that long-term debts represent approximately 32.07 percent of total assets. That proves that Saudi firms in the basic material sector depend on long-term funding their operations compared with short-term debts. 
Table 1. Descriptive statistics of the variables.

\begin{tabular}{ccccccc}
\hline & $R O E$ & $S D A$ & $L D A$ & $D A$ & Size & $S G$ \\
\hline Mean & 8.36813 & 8.4525 & 32.079 & 40.606 & 8.409 & 1.36 \\
Standard Error & 0.97575 & 1.34917 & 2.2564 & 1.8915 & 0.25302 & 0.61 \\
Median & 8.74 & 4.2 & 36.17 & 45.005 & 8.605 & 0.36 \\
Mode & 14.2 & 0 & 0 & 0 & 12.15 & 0 \\
Standard Deviation & 8.7274 & 12.0673 & 20.182 & 16.918 & 2.263077 & 5.43 \\
Sample Variance & 76.1674 & 145.62 & 407.31 & 286.23 & 5.121518 & 29.5 \\
Kurtosis & 2.90347 & 3.61063 & -1.404 & -0.359 & 5.648078 & 7.45 \\
Skewness & -0.4959 & 2.19621 & -0.14 & -0.617 & -1.57483 & 1.01 \\
Range & 61.72 & 46.3 & 64.83 & 69.17 & 12.15 & 44 \\
Minimum & -26.16 & 0 & 0 & 0 & 0 & -20 \\
Maximum & 35.56 & 46.3 & 64.83 & 69.17 & 12.15 & 24.3 \\
Sum & 669.45 & 676.2 & 2566.3 & 3248.5 & 672.72 & 109 \\
Count & 80 & 80 & 80 & 80 & 80 & 80 \\
Confidence Level (95.0\%) & 1.94219 & 2.68545 & 4.4913 & 3.765 & 0.503623 & 1.21 \\
\hline
\end{tabular}

The variable $D A$ measures the ratio of total debt to total assets. The average value of this variable is 40.60 percent, with a median of 45 percent, which illustrates that the companies have financial leverage with a large percentage of total debt being long-term. The average sales growth is 1.36 percent, and the average firm size measured by logarithm of sales, lagged by one year, came to 8.409 .

\section{Correlation Coefficient}

Table 2 interprets the Pearson correlation for the variables that used in the regression model which the firm's profitability is positively correlated with the short-term debt 0.064 , negative relationship with long-term debt and total debt -0.248 and -0.249 respectively, in the basic material sector. The positive correlations explain that short-term debt in the capital structure improves the profitability of the firm and long-term debt and total debt in the capital structure downsize the profitability.

\section{Regression Analysis}

Table 3 shows a significantly positive relationship between short-term debt and profitability 0.878 . A significantly positive association is between long-term debt and profitability 0.638 . A significantly positive association is between total debt and profitability 0.616 . That refers to an increase in the short-term and long-term debt, and total debt position is associated with an increase in profitability. The results also show that profitability increases with one of control variables, significant in sales growth 0.868 , but not significant in size 0.002 .

Table 4 shows that short-term debt to total assets ratio $(S D A)$ insignificant $75 \%$ because it is higher than $5 \%$. Long-term debt to total assets ratio $(L D A)$ show insignificant $72 \%$ because it is higher than $5 \%$. The total debt to total assets 
ratio $(D A)$ is obvious insignificant $79 \%$ because it is higher than $5 \%$. But coefficient of $D A$ show positive value $44 \%$, which mean if the total debt goes up the profitability well goes up and if goes down the profitability well goes down.

Table 5 illustrates that short-term debt to total assets ratio $(S D A)$ insignificant $52 \%$ because it is higher than $5 \%$. Long-term debt to total assets ratio $(L D A)$ show insignificant $50 \%$ because it is higher than $5 \%$. The total debt to total assets ratio $(D A)$ is obvious insignificant $56 \%$ because it is higher than $5 \%$.

Table 6 shows that probability value is $4 \%$, which is less than $5 \%$, so we reject the null hypothesis and accept alternative hypothesis, which mean fixed effect model, is appropriate.

Table 7 summarizes the all previous analysis and giving the ending results of the paper. The long-term and short-term debt ratio shows negative relationship with profitability while total debt ratio shows positive relationship with the profitability.

Table 2. Correlation for variables at level values.

\begin{tabular}{ccccccc}
\hline & ROE & $S D A$ & $L D A$ & $D A$ & Size & $S G$ \\
\hline ROE & 1 & & & & & \\
$S D A$ & 0.0640636 & 1 & & & & \\
$L D A$ & -0.2479924 & -0.551204 & 1 & & & \\
$D A$ & -0.248687 & 0.0532543 & 0.803301 & 1 & & \\
Size & 0.3875937 & 0.0286031 & -0.163842 & -0.175377 & 1 & \\
$S G$ & 0.0327496 & -0.133294 & 0.203707 & 0.165036 & 0.075746 & 1 \\
\hline
\end{tabular}

Table 3. Regression analysis

\begin{tabular}{ccccc}
\hline Variable & Coefficient & Std. Error & t-Statistic & Prob. \\
\hline$C$ & 0.700446 & 4.546921 & 0.154048 & 0.8780 \\
$S D A$ & -0.811152 & 1.714488 & -0.473116 & 0.6375 \\
$L D A$ & -0.862960 & 1.713252 & -0.503697 & 0.6160 \\
$D A$ & 0.759333 & 1.712989 & 0.443280 & 0.6589 \\
$S G$ & 0.032750 & 0.195697 & 0.167349 & 0.8676 \\
Size & 1.347150 & 0.412525 & 3.265624 & 0.0017 \\
\hline
\end{tabular}

Table 4. Fixed effect model.

\begin{tabular}{ccccc}
\hline Variable & Coefficient & Std. Error & t-Statistic & Prob. \\
\hline$C$ & 14.21439 & 2.543705 & 5.588065 & 0.0000 \\
$L D A$ & -0.516768 & 1.664217 & -0.310518 & 0.7571 \\
$D A$ & -0.599432 & 1.668703 & -0.359220 & 0.7206 \\
\hline
\end{tabular}


Table 5. Random effect model.

\begin{tabular}{ccccc}
\hline Variable & Coefficient & Std. Error & t-Statistic & Prob. \\
\hline $\mathrm{C}$ & 13.24424 & 2.519425 & 5.256852 & 0.0000 \\
$S D A$ & -0.998127 & 1.570299 & -0.635629 & 0.5269 \\
$L D A$ & -1.058185 & 1.574266 & -0.672177 & 0.5035 \\
$D A$ & 0.923643 & 1.569128 & 0.588634 & 0.5579 \\
\hline
\end{tabular}

Table 6. HAUSMAN test.

\begin{tabular}{cccc}
\hline Test Summary & Chi-Sq. Statistic & Chi-Sq. d.f. & Prob. \\
\hline Cross-section random & 7.973669 & 3 & 0.0466 \\
\hline
\end{tabular}

Table 7. Hypotheses testing.

\begin{tabular}{ccc}
\hline No & Hypotheses & Null \\
\hline H01 & There is a positive effect of short-term debt on total assets and profitability. & Reject \\
H02 & There is a positive effect of long-term debt on total assets and profitability. & Reject \\
H03 & There is a positive effect of total debt on total assets and profitability. & Accept \\
\hline
\end{tabular}

\section{Summary and Conclusions}

The capital structure is a crucial tool to fund the prospect projects by mixing of internal fund (equity) and external fund (debt), to describe capital structure through calculating the ratio of equity and the ratio of debts to total capital paid, can also be described by the leverage ratio. Capital structure has direct correlated with average cost of capital and it is one elements of firms' valuation if the capital structure changes the average will change which leads to change in the value of firm.

This study, investigates the relationship between the capital structure and profitability on the eight firms, which are Saudi Basic Industries Co. (SABIC), Zamil Industrial Investment Co. (ZIIC), Saudi Kayan Petrochemical Co. (KAYAN), Saudi Arabian Mining Co. (MAADEN), Yanbu National Petrochemical Co. (YANSAB), Sahara International Petrochemical Co. (SIPCHEM), Saudi Steel Pipe Co. (SSP) and Saudi Industrial Investment Co. (SIIG) which operate in the basic materials sector in Saudi Arabia during the period from 2009 to 2018. The dependent variable is return on equity $(R O E)$, while the independent variables are the ratio of short-term debt to total assets $(S D A)$, the ratio of long-term debt to total assets $(L D A)$, and the ratio of total debt to total assets $(D A)$. The results illustrate a negative relationship between short-term debt to total assets ratio $(S D A)$ and return in equity ratio $(R O E)$, and this complements with studies like Hamid and others (2015) and Abeywardhana (2015). A negative relationship is between long-term debt to total assets ratio $(L D A)$ and return in equity ratio $(R O E)$, and this complements with studies like El-Sayed Ebaid (2009) and Salawu and Awolowo (2007). And positive relationship is between total debts to total 
assets ratio $(D A)$ and return in equity ratio $(R O E)$, and this complements with studies like Abor (2005) and Hamid and others (2015). According to correlation model, the results illustrate a positive relationship between short-term debt to total assets ratio $(S D A)$ and return on equity ratio $(R O E) 6 \%$, a positive relationship between long-term debt to total assets ratio $(L D A)$ and return on equity ratio $(R O E) 25 \%$, and a negative relationship between total debt to total assets ratio $(D A)$ and return on equity ratio $(R O E)-25 \%$. In contrast, the control variables show a positive relationship between the size of firm (SIZE) and return on equity ratio $(R O E) 29 \%$, and a positive relationship between the percentage change in sales $(S G)$ and return on equity $(R O E) 3 \%$. The relying on one source of debt either short-term debt or long-term debt will decrease the profitability and make the investment in the firms less incentives. In contrast, the managers of firms that take decide to mix between the short-term debt and long-term debt will lead to increase the profitability and make the firms more liquidity and solvency to meet his current liabilities and non-current liabilities. Furthermore making firms attractive to flow the monies from investors leads to expand the operations and grow and maximize the wealth of shareholders. According to Hausman Test, it is shown that probability value is less than $5 \%$, which means rejecting the null hypothesis and accepting alternative hypothesis so the fixed effect model is the appropriate mode. An explanation of covariance is that the values of the short and long-term debt ratios to total assets are negative -56 and -60 respectively, indicating that these two variables cause a decrease in profitability; on the contrary, the ratio of total debt to total assets showed a positive value, which indicates that the total short and long-term debts combined are not alone; they will increase profitability.

The recommends:

1) The firms must use both of short-term debt and long-term debt to fund their operations and increasing profitability.

2) The study is limited to the sample of eight Saudi Arabia basic materials sector. Future research should increase the sample and investigation of multiple sectors.

\section{Conflicts of Interest}

The author declares no conflicts of interest regarding the publication of this paper.

\section{References}

[1] Hamid, M.A., Abdullah, A. and Kamaruzzaman, N.A. (2015) Capital Structure and Profitability in Family and Non-Family Firms: Malaysian Evidence. Procedia Economics and Finance, 31, 44-55.

https://www.sciencedirect.com/science/article/pii/S2212567115011302 https://doi.org/10.1016/S2212-5671(15)01130-2

[2] Yapa Abeywardhana, D. (2015) Capital Structure and Profitability: An Empirical Analysis of SMEs in the UK. Journal of Emerging Issues in Economics, Finance and 
Banking (JEIEFB), 4, 1661-1675.

https://papers.ssrn.com/sol3/papers.cfm?abstract_id=2816487

[3] Ebaid, I.El-S. (2009) The Impact of Capital-Structure Choice on Firm Performance: Empirical Evidence from Egypt. The Journal of Risk Finance, 10, 477-487. https://doi.org/10.1108/15265940911001385

[4] Abor, J. (2005) The Effect of Capital Structure on Profitability: An Empirical Analysis of Listed Firms in Ghana. The Journal of Risk Finance, 6, 438-445. https://doi.org/10.1108/15265940510633505

[5] Jensen, M.C. and Meckling, W.H. (1976) Theory of the Firm: Managerial Behavior, Agency Costs and Ownership Structure. Journal of Financial Economics, 3, 305-360. https://www.sciencedirect.com/science/article/pii/0304405X7690026X https://doi.org/10.1016/0304-405X(76)90026-X

[6] Hovakimian, A., Opler, T. and Titman, S. (2001) The Debt-Equity Choice. Journal of Financial and Quantitative Analysis, 36, 1-24.

https://www.jstor.org/stable/2676195?seq=1 https://doi.org/10.2307/2676195

[7] Azhagaiah, R. and Gavoury, C. (2011) The Impact of Capital Structure on Profitability with Special Reference to IT Industry in India. Managing Global Transitions: International Research Journal, 9, 371-392.

https://core.ac.uk/download/pdf/6428696.pdf

[8] Taub, A.J. (1975) Determinants of the Firm's Capital Structure. The Review of Economics and Statistics, 57, 410-416.

https://www.jstor.org/stable/1935900?seq=1 https://doi.org/10.2307/1935900

[9] Roden, D.M. and Lewellen, W.G. (1995) Corporate Capital Structure Decisions: Evidence from Leveraged Buyouts. Financial Management, 24, 76-87.

https://www.jstor.org/stable/3665536?seq=1 https://doi.org/10.2307/3665536

[10] Ghosh, A. and Jain, P.C. (2000) Financial Leverage Changes Associated with Corporate Mergers. Journal of Corporate Finance, 6, 377-402.

https://www.sciencedirect.com/science/article/pii/S0929119900000079 https://doi.org/10.1016/S0929-1199(00)00007-9

[11] Hadlock, C.J. and James, C.M. (2002) Do Banks Provide Financial Slack? the Journal of Finance, 57, 1383-1419. https://doi.org/10.1111/1540-6261.00464

[12] Salawu, R.O. and Awolowo, O. (2009) The Effect of Capital Structure on Profitability: An Empirical Analysis of Listed Firms in Nigeria. The International Journal of Business and Finance Research, 3, 121-129.

https://scholar.google.com/scholar?hl=ar\&as_sdt=0\%2C5\&q=\%5B12\%5D\%09Salawu $\% 2 \mathrm{C}+$ Rafiu+Oyesola $\% 2 \mathrm{C}+$ and + Obafemi+Awolowo. $+\% 22 \mathrm{The}+$ effect + of + capital + stru cture+on+profitabil-ity $\% 3 \mathrm{~A}+\mathrm{An}+$ empirical+analysis+of+listed+firms+in+Nigeria. $\% 2$ 2+The+International+Journal+of+Business+and+Finance+Research $+3.2+\% 282009 \%$ 29\%3A+121-129.\%E2\%80\%8F\&btnG

[13] de Mesquita, J.M.C. and Lara, J.E. (2003) Capital Structure and Profitability: The Brazilian Case.

[14] Gill, A., Biger, N. and Mathur, N. (2011) The Effect of Capital Structure on Profitability: Evidence from the United States. International Journal of Management, 28, 3. https://www.researchgate.net/profile/Amarjit_Gill/publication/281004540_The_effe cts_of_capital_structure_on_profitability_Evidence_from_United_States/links/5787 68ee08ae78057de18ede.pdf 
[15] San, O.T. and Heng, T.B. (2011) Capital Structure and Corporate Performance of Malaysian Construction Sector. International Journal of Humanities and Social Science, 1, 28-36.

https://scholar.google.com/scholar?hl=ar\&as_sdt=0\%2C5\&q=\%5B15\%5D\%09San $\%$ 2C+Ong+Tze\%2C+and+Teh+Boon+Heng.+\%22Capital+structure+and+corporate + performance+of+Malay-sian+construction+sector.\%22+International+Journal+of +Humanities+and+Social+Science+1.2+\%282011\%29\%3A+28-36.\%E2\%80\%8F\&bt nG

[16] Soumadi, M.M. and Hayajneh, O.S. (2012) Capital Structure and Corporate Performance Empirical Study on the Public Jordanian Shareholdings Firms Listed in the Amman Stock Market. European Scientific Journal, 8, 173.

https://scholar.google.com/scholar?hl=ar\&as_sdt=0\%2C5\&q=Soumadi\%2C+Mustaf a+M.\%2C+and+Osama+Suhail+Hayajneh.+\%22Capital+structure+and+corporate +perfor-mance+empirical+study+on+the+public+Jordanian+shareholdings+firms + listed+in+the+Amman+stock+market. $\% 22+$ European+Scientific+Journal+8.22+ \%282012\%29.\%E2\%80\%8F\&btnG

[17] Salim, M. and Yadav, R. (2012) Capital Structure and Firm Performance: Evidence from Malaysian Listed Companies. Procedia-Social and Behavioral Sciences, 65, 156-166. https://www.sciencedirect.com/science/article/pii/S1877042812050902 https://doi.org/10.1016/j.sbspro.2012.11.105

[18] Velnampy, T. and Niresh, J.A. (2012) The Relationship between Capital Structure and Profitability. Global Journal of Management and Business Research, 12, 66. http://journalofbusiness.org/index.php/GJMBR/article/view/766

[19] Addae, A.A., Nyarko-Baasi, M. and Hughes, D. (2013) The Effects of Capital Structure on Profitability of Listed Firms in Ghana. European Journal of Business and Management, 5, 215-229.

[20] Ahmad, T. (2014) Impact of Capital Structure on Profitability: An Empirical Analysis of Cement Sector of Pakistan. Research Journal of Finance and Accounting, 5, 49-54.

https://scholar.google.com/scholar?hl=ar\&as_sdt=0\%2C5\&q=Impact+of+Capital+Stru cture+on+Profitability\%3A+An+Empirical+Analysis+of+Cement+Sector+of+Pakistan $\underline{\text { \&btnG }}$

[21] Tailab, M. (2014) The Effect of Capital Structure on Profitability of Energy American Firms. International Journal of Business and Management Invention, 3, 54-61. https://papers.ssrn.com/sol3/papers.cfm?abstract_id=3251675

[22] Yegon, C., et al. (2014) The Effects of Capital Structure on Firm’s Profitability: Evidence from Kenya's Banking Sector. Research Journal of Finance and Accounting, 5, 152-159.

https://scholar.google.com/scholar?hl=ar\&as_sdt=0\%2C5\&q=Yegon $\% 2 \mathrm{C}+\mathrm{Charles} \% 2$ C+et+al.+\%22The+Effects+of+Capital+Structure+on+Firm\%E2\%80\%9F+s+Profitabi li-ty $\% 3 \mathrm{~A}+$ Evidence+from + Kenya $\% \mathrm{E} 2 \% 80 \% 9 \mathrm{~F}+\mathrm{s}+$ Banking+Sector. $\% 22+$ Research+Jo urnal+of+Finance+and+Accounting $+5.9+\% 282014 \% 29 . \% \mathrm{E} 2 \% 80 \% 8 \mathrm{~F} \& \mathrm{btnG}$

[23] Movalia, N.P. (2015) A Study on Capital Structure Analysis and Profitability of Indian Tyres Industry. Pacific Business Review International, 8, 78.

https://scholar.google.com/scholar?hl=ar\&as_sdt=0\%2C5\&q=A+Study+on+Capital + Structure+Analysis+and+Profitability+of+Indian+Tyres+Industry\&btnG

[24] Semuel, H. and Widjojo, L. (2016) The Effect of Capital Structure on Profitability of Property and Construction Companies in Indonesia. Diss., Petra Christian University, Wonocolo. http://repository.petra.ac.id/17960

[25] Anarfo, E.B. and Appiahene, E. (2017) The Impact of Capital Structure on Banks' 
Profitability in Africa. Journal of Accounting and Finance, 17, 55.

https://www.articlegateway.com/index.php/JAF/article/view/966

[26] Singh, B. and Singh, M. (2016) Impact of Capital Structure on Firm's Profitability: A Study of Selected Listed Cement Companies in India. Pacific Business Review International, 8, 46-54.

https://scholar.google.com/scholar?hl=ar\&as_sdt=0\%2C5\&q=Impact+of+Capital+Stru cture+on+Firm $\% 27 \mathrm{~s}+$ Profitability $\% 3 \mathrm{~A}+\mathrm{A}+$ Study+of+selected+listed+Cement+Compa nies+in+India\&btnG 